RJOAS, 5(101), May 2020

DOI 10.18551/rjoas.2020-05.03

\title{
DETERMINANT ANALYSIS OF DISABLED CHILDREN EDUCATION IN BALI PROVINCE, INDONESIA
}

\author{
Serinah I Wayan*, Doctorate Candidate \\ Faculty of Economics and Business, University of Udayana, Indonesia \\ Utama Made Suyana, Setiawina Nyoman Djinar, Yuliarmi Ni Nyoman, Lecturers \\ Faculty of Economics and Business, University of Udayana, Indonesia \\ *E-mail: wasarbali@yahoo.com
}

\begin{abstract}
One of the goals of a country is to prosper its people including people with disabilities. The welfare of persons with disabilities can be achieved through increased independence, the educational process, and patterns of care for people with disabilities. The education process and the burden of care to realize the independence of persons with disabilities are influenced by the level of disability, family economy, family environment, school environment, and community environment. This study aims to 1) analyze the level of disability, family economy, family environment, school environment, and community environment towards the burden of childcare; 2) analyze the level of disability, family economy, family environment, school environment, community environment, and the burden of child care for children's education; and 3) analyze the level of disability, family economics, family environment, school environment, community environment, the burden of care, and education of children towards the independence of persons with disabilities; 4) analyze whether the burden of care mediates the effect of variable levels of disability, family economy, family environment, school environment, community environment on the education of children with disabilities; and 5) analyze whether the education of children with disabilities mediates the effects of variable levels of disability, family economy, family environment, school environment, community environment on the independence of persons with disabilities in the Province of Bali. This study was designed using quantitative methods with 177 respondents with disabilities taken by probability sampling with proportionate stratified random sampling techniques. The analytical model used is Partial Least Square (PLS) with Structural Equation Modeling. The results showed that: 1) variables of the level of disability, family economy, family environment, and school environment directly had a positive and significant effect on the burden of caregiving and only the community environment had a direct but not significant effect on the burden of care; 2) variables of the level of disability, family economy, family environment, school environment, and community environment directly have a positive and significant effect on the education of children with disabilities and the independence of persons with disabilities; 3 ) the burden of care mediates the influence of the level of disability, family economy, family environment, and school environment significantly on the education of children with disabilities. While the influence of the community environment on the education of children with disabilities through the burden of caregiving as a mediating variable has no significant effect; 4) education of children with disabilities mediates the influence of the level of disability, family economy, family environment, school environment, and community environment significantly on the independence of persons with disabilities in the province of Bali. Based on the results of this study, it is hoped that the government, NGOs and social organizations to encourage increased access and quality of education for children with disabilities, skills training and empowerment of persons with disabilities to foster independence and fulfill the rights of persons with disabilities.
\end{abstract}




\section{KEY WORDS}

Rate of disability, family economy, environment, education for disabled children, independence of the disabled.

Realizing people's welfare is the goal of the state which is implemented through a development program. To measure the level of welfare of the population the United Nations Development Program (UNDP) in 1990 introduced the Human Development Index which is published periodically in the Human Development Report as a measure of the achievement of development or the level of welfare of the population of a country or region. Todaro (2004) states that the basic indicators of development are real income, health, and education. Education (including children with disabilities) will determine the achievement of development and community welfare. Data from the 2017 Province of Bali Social Service in Atu Dewi (2018) states that the total population of people with disabilities is 43,040 people, consisting of persons with disabilities based on disability as many as 25,013 people and the elderly (elderly) as many as 18,027 people. Based on the 2019 Education Profile and Information at the Bali Provincial Education Office, School for the disabled (SLB) students in 2018/2019 Academic Year were 2,209 people and there were still school-aged children with disabilities who were not attending school. There are several risk factors and protective factors that interact with each other as an ecological sub-system in children, namely: individual characteristics, family background, school conditions, education system, and wider socio-economic conditions so that the result of children not attending school. Bear, et al (2006) revealed, there are some reasons why a student drops out of school that varies with each individual. In the Individual Education Program (IEP) mentioned to find out the differences between individuals and the causes of children with disabilities leaving school is to look at the fixed characteristics of children related to their needs. Specific disability is a very significant factor as a cause of dropping out, in addition to weak individual factors (disability), family (economic conditions and parents 'expectations), and school (the quality of students' relationships with teachers and peers) is also a driver to quit school. It is seen that the level of disability, family economy, family environment, school environment, community environment are determinants that influence the education of children with disabilities.

The purpose of education for children with disabilities is to realize independence in activities, business, and life with their families. Children with disabilities are far more likely to face difficulties in finding work and accessing welfare. However, they remain an important part of the population that needs to develop their knowledge, skills, and talents that are sometimes underexplored and not yet utilized for their independence (Singal, et al, 2017). Educational development is the second priority program in the 2018-2023 Bali Regional Development Vision namely "Nangun Sat Kerthi Loka Bali", so examining the real condition of educational services for persons with disabilities is an interesting problem to study, especially the factors that influence the education of children with disabilities in realizing the independence of persons with disabilities in the Province of Bali.

The purpose of this study is to analyze: 1) the effect of the level of disability, family economy, family environment, school environment and community environment on the burden of care; 2) the influence of the level of disability, family economy, family environment, school environment and community environment on the education of children with disabilities; 3) the influence of the level of disability, family economy, family environment, school environment and community environment on the independence of persons with disabilities; 4) analyze whether the burden of care mediates the influence of the level of disability, family economy, family environment, school environment and community environment on the education of children with disabilities; and 5) analyze whether the education of children with disabilities mediates the influence of the level of disability, family economy, family environment, school environment and community environment on the independence of persons with disabilities in the Province of Bali. 


\section{LITERATURE REVIEW}

Humans are social creatures, like it or not, all activities in our lives are interrelated with others as an integrated system (Jones, 1997). The condition of well-being refers to the term social welfare, which is a condition of meeting material and non-material needs. Midgley (2000) defines social welfare as "... a condition or state of human well-being." Prosperous conditions occur when human life is safe and happy because the basic needs for nutrition, health, education, shelter, and income can be met, and obtain protection from the risks that threaten their lives.

In-Law Number 8 of 2016 concerning Persons with Disabilities, the social welfare rights for persons with disabilities include the right to social rehabilitation, social security, social empowerment, and social protection. The welfare of persons with disabilities is achieved if they move out of poverty and / or are not mired in the poverty circle by Chambers. 1983 in Kadji (2013) was mentioned as a disadvantage that surrounded the lives of poor people or families, namely: (1) poverty; (2) physical weakness; (3) vulnerability; (4) isolation; and (5) powerlessness. This disadvantage causes a tangled thread of poverty in poor families, especially people with disabilities because it enters the poverty trap scheme that does not end (Salim, 1980).

The way out of the poverty trap is with human development. Gilley and Eggland (1996) stated human development refers to the advancement of competencies, namely knowledge, skills, and improvement of human behavior itself, both for individual interests and for the benefit of the organization. Braunholtz (2007) notes that not all chronic poor people are born in long-term poverty, but many fall into chronic poverty after a series of shocks that they cannot recover, including health, injury, and disability. In the long run, people who are economically poor due to health, age, physical or mental disability are more likely to face lasting poverty, because the solutions available to them are limited (Braunholtz, 2007). Being disabled or families with disabilities tend to remain poor and at greater risk of passing on their poverty to the next generation. Sakamota and Power (1995) stated that poor children and children with disabilities did not excel at school and most of them had low expectations. Disabled and poor children will not get access to a quality education because of poverty and negative perceptions in the school environment. Special education and inclusion in education for students who have difficulty in following the learning process due to physical, emotional, mental, social, and/or potential disabilities and special talents, to optimally develop students' potential according to their abilities. These students are children with disabilities consisting of: visually impaired, deaf, deaf, mentally retarded, mentally disabled, tunalaras, learning difficulties, slow learning, autistic, have motor impairments, become victims of narcotics abuse, illegal drugs, and other addictive substances, and have other disorders and disorders double tuna (Winarsih, et al. 2013).

Education is one of the roads to the independence of people with disabilities. The welfare of persons with disabilities can be achieved if they can move independently and have competence, namely knowledge, skills, and behavior to work or open a business independently by their disability. Independence and competency of persons with disabilities will grow through the education process, namely self-development programs and vocational / skills education through formal education (special education/inclusion), non-formal education, and also informal education.

In the theory of independence developed by Steinberg (1995) the term independence means independence which lexically means independence or freedom. Conceptually independence refers to the capacity of individuals to treat themselves. Steinberg (1995) states that "independence generally refers to individuals' capacity to behave on their own". According to Monks, et al (2006) an independent person will exhibit explorative behavior, be able to make decisions, be confident, and be creative. It is also able to act critically, is not afraid to do something, has satisfaction in carrying out its activities, can accept reality and can manipulate the environment, interact with peers, focus on goals and be able to control themselves. Santrock 
(2003) states, the factors that influence and shape independence are the environment, parenting, and education. The internal environment (family) and external environment (community) will shape a person's personality and independence. The role and parenting of parents are very influential in instilling the values of a child's independence. While education contributes to the formation of one's independence, namely social interaction and intelligence. Social interaction trains children to adjust and take responsibility for what is done so that children can solve the problems faced, while intelligence is an important factor that influences the process of determining attitudes, decision making, problem-solving, and adjustment.

The independence of persons with disabilities can be realized through self-development education called the Activity of Daily Living (ADL) or daily activities. The self-development program aims to practice personal skills that have a direct impact and relate directly to other individuals in the community. Skills that are trained and taught are individual needs that must be done alone without the help of others so that persons with disabilities can take care of themselves in their daily routine activities (Widya, 2003). This self-development must be carried out sustainably, so that independence, skills, and abilities grow to create independent businesses, work opportunities or work following their expertise and competencies, including fostering emotional independence and behavior. The independence of persons with disabilities can be seen in Astuti's research (2016) where the characteristics of independence are: 1) able to take the initiative; 2) able to overcome obstacles or problems encountered; 3) have confidence and can do things without the help of others; 4) have a desire to develop a business; 5) has a desire to compete for progress for his good; and 6) take responsibility for what he does. Independence is influenced by various factors, namely parenting factors in the family and community environment. Physiological conditions such as the state of the body, physical health, gender, and psychological conditions also influence, because one's intelligence and thinking ability can be changed and developed through the environment.

Educational services for people with disabilities are a must in education for all. The international provisions that form the basis are the Universal Declaration of Human Rights in 1946, the UNESCO Convention on Discrimination in Education in 1960, and the 1989 Convention on the Rights of the Child. Salamanca Statement and Framework for Action for Disability Education in 1994, UN Convention on the Rights of Persons with Disabilities in 2006. These international provisions are a reference of all countries in education services for persons with disabilities with the principle of equal rights, equality, and justice. Indonesia has ratified the results of the Convention on the Rights of Persons with Disabilities (Convention on the Right Persons With Disabilities) as outlined in Law Number 19 of 2011. UNESCO (2009) revealed, there are three approaches to educating children with disabilities, namely: 1) Segregation, children with disabilities are educated in special schools or at home; 2) Inclusive education, children with disabilities learn effectively in public schools where the whole system has been changed to meet all children's needs; and 3) Integrated education, children with disabilities attend special classes or units in public schools. Inclusion education policy in Indonesia began since the issuance of the Circular of the Director-General of Elementary Education and Education Ministry of National Education No.380 / C.C6 / MN / 2003 on January 20, 2003, reinforced by Permendiknas No. 70 of 2009 concerning Inclusive Education, which seeks to accommodate education for all regardless of race, religion, and potential of students. Explained, Zaitun (2017) the goal of inclusive education is to encourage the realization of full disability participation in people's lives. However, in practice, the inclusive education system in Indonesia still leaves the issue of tugging between the government and education practitioners, in this case, the teachers. The educational attainment of children with disabilities through special education and inclusive education is highly dependent on the disability conditions experienced by children, the socioeconomic conditions of the family, because the disability education process of children needs to be supported by high enough costs, conditions of the family environment, school 
environment, and the community environment also influence the sustainability of children's education

Parents who have children with less normal conditions will surely experience depression, feelings of sadness and even feel unprepared to accept the condition suffered by their children for a variety of reasons. Depression according to Beck (1985), is a "primary mood disorder" or as an "affective disorder". Beck views depression as follows: (1) Depression is a prolonged sadness and an apathetic state of mind (affective component); (2) Depression is a wrong way of thinking in looking at reality outside and within oneself, so that negative self-concepts are formed which continue to feelings of inferiority (the cognitive component); (3) Depression is a disorder of physiological function which, among others, causes difficulty sleeping and loss of appetite and sexual (physiological components); (4) Depression is a loss of the ability to function properly and a loss of drive and energy to act (a component of behavior). Several factors that contribute to increasing parenting stress are due to the child's condition, namely: lack of intellectual function, physical limitations, low self-care skills, and limited social skills of children (Lessenberry \& Rehfeldt, 2004). These conditions need a treatment program to provide targeted activities when they have free time, avoid negative effects, do not harm, and do not disturb the environment. Parents who have a child with a disability face the challenges and burdens of care that take up family resources, namely psychological burdens, caregiving time, support needs of caregivers, and special costs of care and care (Jemta, et al, 2008).

The education process is one form of fulfilling the basic rights of children, namely the right to grow and develop and learning needs. The fulfillment process will not be separated from the influence of the environment, especially the family environment, community environment, and the school environment both through informal education, formal education, and non-formal education. Mishra \& Azeez (2014) stated, "Family is the most influential agent among the different social factors that significantly influence the growth and development of any child". In the family environment, economic status, social status, parental education level, income, and care burden affect the development of children's education. Rumberger \& Larson's research (1998) reveals the relationship between educational performance with individual students, the school environment, family conditions, and community environmental conditions, as outlined in the "Conceptual Framework for Studying Student Educational Performance". Within the framework of this concept, educational performance will be influenced by the child's individual background as seen from a gender perspective, attitudes, or perceptions about education and the educational background of parents. This background directly affects the social conditions in schools and the academic condition of students. In line with Rumberger \& Larson's work scheme, Santrock (2010), states, the ecological system theory developed by Urie Bronfenbrenner in 1986, focuses primarily on the social context in which children live and those that influence children's development. Urie Bronfenbrenner's Ecological Systems Theory defines and understands human development in the context of the system of relationships that shape the person's environment. Bronfenbrenner's Ecological Systems Theory: "The ecology of human development is the scientific study of the progressive, mutual accommodation throughout the life course between the active, the growing human being and the changing properties of the immediate settings in the developing person lives" (Johnson, 2008). Bronfenbrenner's Ecological Systems Theory is also used to know and understand the processes and factors that influence the education of children with disabilities. Mantey (2014) states the Bronfenbrenner Theory Model is used to explain the education of children with disabilities in the context of an ideal inclusive education. In this model, it will be seen the interaction process that is likely to occur in the context of children's ecosystems and critical understanding of the education of persons with disabilities. This system will explain the systemic influence on the development of children with disabilities in education, such as Figure 2. 


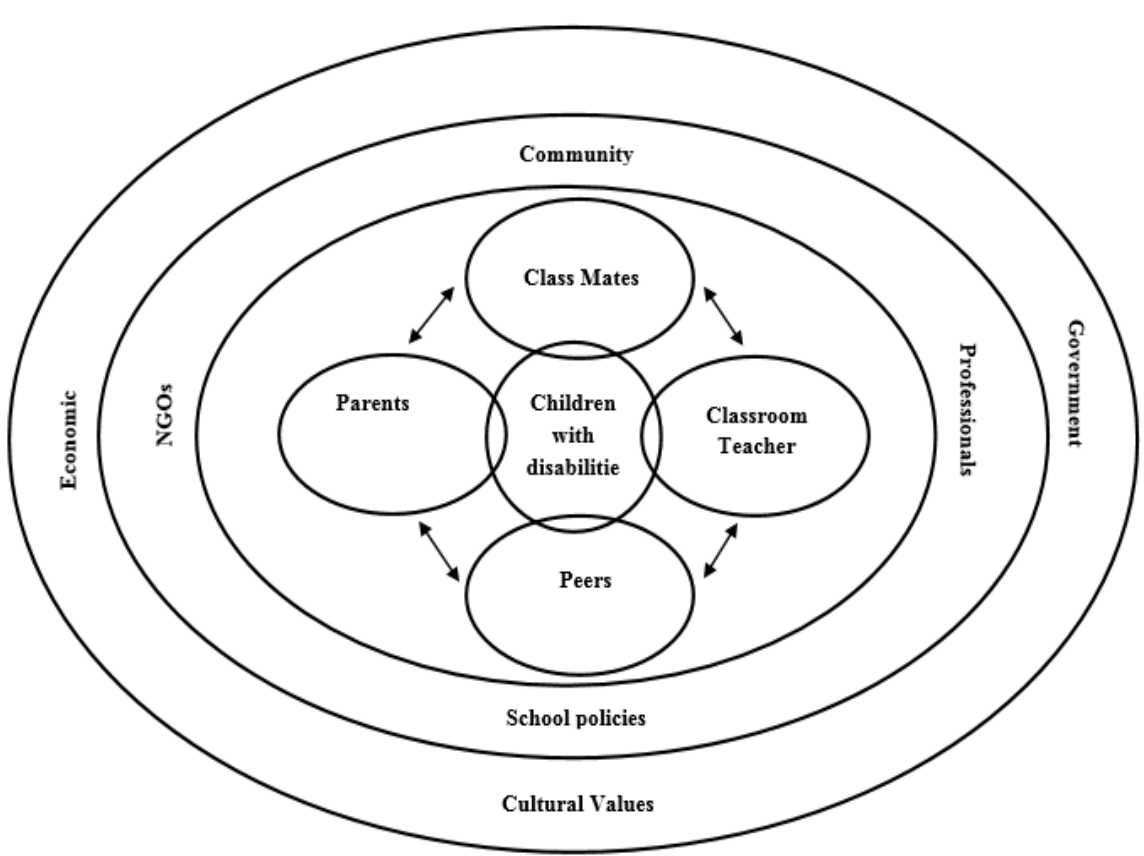

Figure 2 - Bronfenbrenner Ecological System of Disabilities Education (Source: Urie Bronfenbrenner, 1989 in Mantey, 2014)

Factors that influence the education of children with disabilities as subsystems are divided into five systems, namely: microsystems, mesosystems, exosystems, macrosystems, and chronosystems. Figure 4 makes it possible to explore the educational development of children with disabilities that are constructed and constrained by factors operating at different levels. At the microsystem layer, two-way relationships occur that influence each other with individual students. Relationships in the microsystem layer are individual student interactions with parents, class teachers, classmates, school employees. In the mesosystems layer where the factors interact with one another, it also influences individual students, such as the relationship between parents and class teachers, classmates, peers, and school environment. Exosystems are larger social systems such as school and government policies where children do not interact directly, but as recipients of impacts. The structure in this layer affects the child's development when interacting with several other structures in the microsystem. Furthermore, the macrosystem is considered as the outer layer in the child environment. Although it does not become a specific framework, this layer consists of cultural values, customs, beliefs, social systems, and applicable legal rules. The effect of the larger principles defined by the macro system has a tiered effect throughout the interaction of all other layers. Furthermore, the final system is the chronosystem which includes the time dimension related to the child's environment. The elements in this system can be external, such as the time of parental death or internal, such as physiological changes that occur with increasing age of the child. Children with disabilities are central to the system and educational process of children with disabilities, so that individual conditions of children, the level of disabilities experienced by children become part of the microsystem including interactions between children with disabilities and the family environment and family economic conditions. The relationship between parents and schools such as teachers and school managers, school friends, and the school environment is in the mesosystem environment. While school policies or government policies that directly affect the process of children's education are report ecosystems. Furthermore, the macrosystem in the process of education of children with disabilities is the influence of the community environment with cultural values, customs, beliefs, social systems, and the rule of law applicable in society. The final system is the chronosystem 
which includes the time dimension related to the child's environment such as physiological changes that occur with age.

\section{METHODS OF RESEARCH}

Research with a population of people with disabilities in the Province of Bali totalling 25,013 people, the determination of the sample was determined by the proportionate random sampling technique. Using the Slovin method, 177 research respondents. After the data has been collected, validity and reliability tests are performed to determine the validity of the instrument and the level of confidence in the results of a measurement. Collecting data in this study using a questionnaire with a scale of 1 to 5 , and then analyzed with PLS (Partial Least Square) analysis techniques with the model as presented in Figure 3.

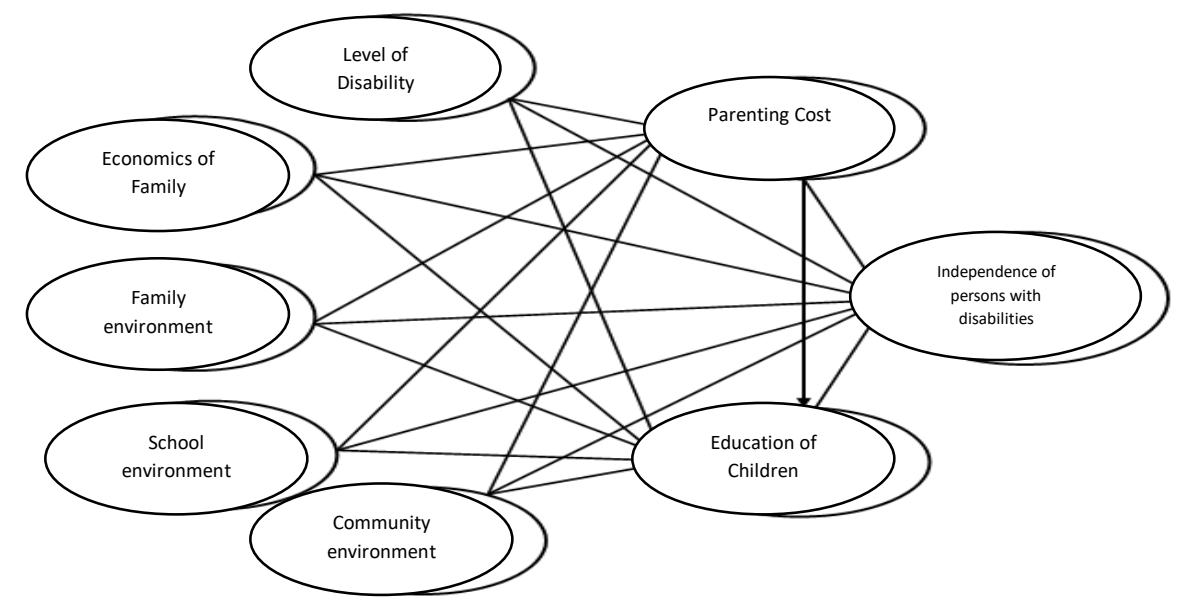

Figure 3 - Research Conceptual Framework

\section{RESULTS AND DISCUSSION}

A validity test is used to test the level of accuracy and accuracy of the instrument that should be measured using a two-tailed test with a significance level of 0.05 . Reliability shows the level of accuracy of the measurement tool. The value of an instrument is said to be reliable if it has a Cronbach's Alpha value $>0.7$ and is still tolerated if $>0.6$. The results of the instrument validity and reliability test can be seen from the results of the Pearson bivariate analysis show that the correlation of all indicator items with total score items is significant $(<0.05)$, so it can be concluded that the research instrument is valid. Likewise, the Cronbach's Alpha value for all items is $>0.70$ so that it is concluded that all instrument items are reliable.

Overall, the full model of the influence of the level of disability, family economy, family environment, school environment, community environment, care burden, education of children with disabilities on the independence of persons with disabilities in Bali Province is presented in Figure 4.

Three values must be considered at this stage, namely convergent validity, discriminant validity, and composite reliability. Convergent validity is used to find out which instrument items can be used as indicators of all latent variables. The results of this test are measured based on the outer loading factor of the construct indicator. The following convergent validity test results are presented in Table 1. Test results Table 1 shows that all outer loading has a value greater than 0.5 so that this measurement can be concluded that it has fulfilled the convergent validity requirements. 


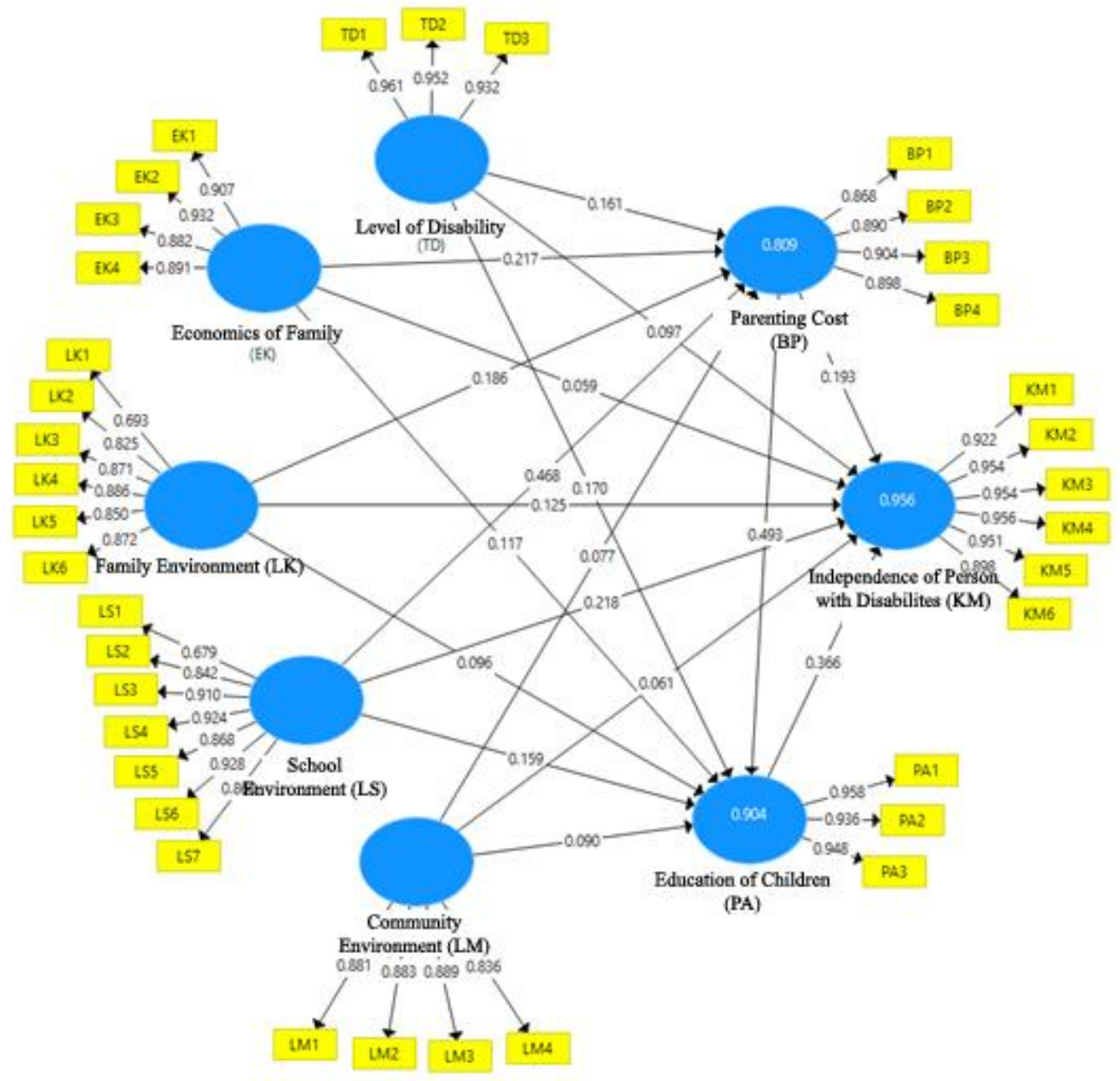

Figure 4 - Full Models of Disability Level, Family Economy, Family Environment, School Environment, Community Environment, Burden of Care and Education of Children with Disabilities Towards Independence of Persons with Disabilities in the Province of Bali

Table 1 - Outer Loading Indicator Against each construct

\begin{tabular}{|c|c|c|c|c|c|c|}
\hline \multicolumn{3}{|c|}{ Relationship between indicators and their constructs } & Loading & Std. Deviation & t-statistic & $\mathrm{P}$ value \\
\hline TD1 & $\leftarrow$ & TD & 0,961 & 0,008 & 119,383 & 0,000 \\
\hline TD2 & $\leftarrow$ & TD & 0,952 & 0,012 & 77,283 & 0,000 \\
\hline TD3 & $\leftarrow$ & TD & 0,932 & 0,021 & 45,462 & 0,000 \\
\hline EK1 & $\leftarrow$ & EK & 0,907 & 0,017 & 54,212 & 0,000 \\
\hline EK2 & $\leftarrow$ & EK & 0,932 & 0,012 & 74,616 & 0,000 \\
\hline EK3 & $\leftarrow$ & EK & 0,882 & 0,021 & 42,036 & 0,000 \\
\hline EK4 & $\leftarrow$ & EK & 0,891 & 0,026 & 34,238 & 0,000 \\
\hline LK1 & $\leftarrow$ & LK & 0,693 & 0,058 & 11,908 & 0,000 \\
\hline LK2 & $\leftarrow$ & LK & 0,825 & 0,033 & 25,089 & 0,000 \\
\hline LK3 & $\leftarrow$ & LK & 0,871 & 0,026 & 33,859 & 0,000 \\
\hline LK4 & $\leftarrow$ & LK & 0,886 & 0,025 & 35,854 & 0,000 \\
\hline LK5 & $\leftarrow$ & LK & 0,850 & 0,038 & 22,631 & 0,000 \\
\hline LK6 & $\leftarrow$ & LK & 0,872 & 0,031 & 28,448 & 0,000 \\
\hline LS1 & $\leftarrow$ & LS & 0.679 & 0.055 & 12,260 & 0.000 \\
\hline LS2 & $\leftarrow$ & LS & 0,842 & 0,045 & 18,745 & 0,000 \\
\hline LS3 & $\leftarrow$ & LS & 0,910 & 0,017 & 54,309 & 0,000 \\
\hline
\end{tabular}


RJOAS, 5(101), May 2020

\begin{tabular}{lclllll} 
LS4 & $\leftarrow$ & LS & 0,924 & 0,013 & 69,939 & 0,000 \\
LS5 & $\leftarrow$ & LS & 0,868 & 0,032 & 27,522 & 0,000 \\
LS6 & $\leftarrow$ & LS & 0,928 & 0,014 & 65,842 & 0,000 \\
LS7 & $\leftarrow$ & LS & 0,860 & 0,022 & 38,285 & 0,000 \\
LM1 & $\leftarrow$ & LM & 0,881 & 0,025 & 35,102 & 0,000 \\
LM2 & $\leftarrow$ & LM & 0,883 & 0,028 & 31,917 & 0,000 \\
LM3 & $\leftarrow$ & LM & 0,889 & 0,025 & 35,084 & 0,000 \\
LM4 & $\leftarrow$ & LM & 0,836 & 0,034 & 24,818 & 0,000 \\
BP1 & $\leftarrow$ & BP & 0,868 & 0,033 & 26,457 & 0,000 \\
BP2 & $\leftarrow$ & BP & 0,890 & 0,020 & 45,038 & 0,000 \\
BP3 & $\leftarrow$ & BP & 0,904 & 0,017 & 54,179 & 0,000 \\
BP4 & $\leftarrow$ & PA & 0,898 & 0.019 & 46,664 & 0,000 \\
PA1 & PA & 0,958 & 0,011 & 89,206 & 0,000 \\
PA2 & $\leftarrow$ & PA & 0,936 & 0,011 & 84,534 & 0,000 \\
PA3 & $\leftarrow$ & KM & 0,948 & 0,013 & 73,889 & 0,000 \\
KM1 & $\leftarrow$ & KM & 0,922 & 0,018 & 52,562 & 0,000 \\
KM2 & KM & 0,954 & 0,010 & 95,738 & 0,000 \\
KM3 & $\leftarrow$ & KM & 0,954 & 0,010 & 94,751 & 0,000 \\
KM4 & $\leftarrow$ & KM & 0,956 & 0,011 & 86,478 & 0,000 \\
KM5 & $\leftarrow$ & KM & 0,951 & 0,011 & 85,613 & 0,000 \\
KM6 & & 0,898 & 0,018 & 50,715 & 0,000 \\
\hline
\end{tabular}

Note: $T D=$ Disability level $L M=$ Community Environment; $E K=$ Family's Economics $B P=$ Parenting Cost; $L K=$ Family Environment $P A=$ Education of disabilities children; $L S=$ School Environment $K M=$ Independence of person with disabilities.

Based on Table 2 it can be seen that all constructs are very good because they have a discriminant validity that is far greater than 0.5 . Discriminant validity of all research variables is reflected in the Average Variance Extracted Value (AVE) of each variable with AVE above 0.70 for Composite Reliability and Cronbach Alpha which exceeds 0.60 . Thus all measurements used in this study are reliable.

Table 2 - Average Variance Extracted (AVE), Composite Reliability (CR)

\begin{tabular}{lccc}
\hline \multicolumn{1}{c}{ Construct } & $\begin{array}{c}\text { Average Variance } \\
\text { Extracted (AVE) }\end{array}$ & $\begin{array}{c}\text { Composite } \\
\text { Reliability }\end{array}$ & $\begin{array}{c}\text { Cronbach's } \\
\text { Alpha }\end{array}$ \\
\hline Parenting Costs (BP) & 0,792 & 0,938 & 0,913 \\
Family Economics (EK) & 0,816 & 0,947 & 0,925 \\
Independence of Persons with Disabilities (KM) & 0,882 & 0,978 & 0,973 \\
Family Environment (LK) & 0,698 & 0,932 & 0,912 \\
Community Environment (LM) & 0,761 & 0,927 & 0,895 \\
School Environment (LS) & 0,744 & 0,953 & 0,941 \\
Disability Children's Education (PA) & 0,897 & 0,963 & 0,943 \\
Disability Level (TD) & 0,900 & 0,964 & 0,944 \\
\hline
\end{tabular}

The goodness of fit structural models in the inner model is tested using relevant predictive values (Q2). The Goodness of structural evaluation shown in Table 3, which contains the Rsquare coefficient for each exogenous variable.

Table 3 - R-square Values

\begin{tabular}{lcc}
\hline \multicolumn{1}{c}{ Variable } & $R$ Square & Information \\
\hline Parenting Costs (BP) & 0,809 & Strong \\
Disability Children's Education (PA) & 0,904 & Strong \\
Independence of Persons with Disabilities (KM) & 0,956 & Strong \\
\hline
\end{tabular}

Predictive value - relevance is obtained by the formula:

$$
Q^{2}=1-\left[\left(1-R_{1}{ }^{2}\right)\left(1-R_{2}{ }^{2}\right) \ldots\left(1-R_{p}{ }^{2}\right)\right]=0,989
$$


The Q2 results show the predictive relevance value is 0.989 . This means that 98.9 percent of the variation in the independence of persons with disabilities can be explained by the variables used in the model. The remaining 1.1 percent is explained by other factors outside the model. With this result, it can be concluded that this model has relevant predictive value.

The model evaluation used the bootstrapping procedure, through the T-statistical significance test of each path coefficient, to test the significance of the construct, with a significance level of $\alpha=5 \%$, where the t-table value was around $=1,645$ for one side. To find out the direct effect between variables can be seen from the results of the analysis of the path coefficients shown in Table 4.

Table 4 - Path Coefficients (Direct Effect between Research Variables)

\begin{tabular}{lccccc}
\hline Path Variable & Coefficient & Standard Deviation & T Statistics & P Values & Keterangan \\
\hline TD $\rightarrow$ BP & 0,161 & 0,065 & 2,470 & 0,014 & Significant \\
EK $\rightarrow$ BP & 0,217 & 0,068 & 3,202 & 0,001 & Significant \\
LK $\rightarrow$ BP & 0,186 & 0,055 & 3,351 & 0,001 & Significant \\
LS $\rightarrow$ BP & 0,468 & 0,060 & 7,833 & 0,000 & Significant \\
LM $\rightarrow$ BP & 0,077 & 0,051 & 1,511 & 0,132 & Not Significant \\
TD $\rightarrow$ PA & 0,170 & 0,060 & 2,823 & 0,005 & Significant \\
EK $\rightarrow$ PA & 0,117 & 0,049 & 2,403 & 0,017 & Significant \\
LK $\rightarrow$ PA & 0,096 & 0,048 & 2,303 & 0,043 & Significant \\
LS $\rightarrow$ PA & 0,159 & 0,072 & 2,195 & 0,029 & Significant \\
LM $\rightarrow$ PA & 0,090 & 0,043 & 2,091 & 0,037 & Significant \\
TD $\rightarrow$ KM & 0,097 & 0,031 & 3,117 & 0,002 & Significant \\
EK $\rightarrow$ KM & 0,059 & 0,032 & 1,869 & 0,062 & Significant \\
LK $\rightarrow$ KM & 0,125 & 0,028 & 4,501 & 0,000 & Significant \\
LS $\rightarrow$ KM & 0,218 & 0,039 & 5,532 & 0,000 & Significant \\
LM $\rightarrow$ KM & 0,061 & 0,026 & 2,337 & 0,020 & Significant \\
BP $\rightarrow$ KM & 0,193 & 0,079 & 2,438 & 0,015 & Significant \\
PA $\rightarrow$ KM & 0,366 & 0,070 & 5,195 & 0,000 & Significant \\
BP $\rightarrow$ PA & 0,493 & 0,111 & 4,445 & 0,000 & Significant \\
\hline
\end{tabular}

Table 4 shows that the community environmental variable (LM) has a positive effect on the caregiving variable (BP), but it is not significant. This relationship is evidenced by the P-Value of the variable greater than 0.05 that is, a $p$-value of 0.132 for two-sided testing or with $t$ arithmetic of 1.511 smaller than t-table of 1.645 with a $p$-value of 0.066 to test one side, so it is declared insignificant because it is greater than 0.05 . In addition to the relationship of the community's environment to the burden of caregiving, all relationships have a positive and significant effect as evidenced by P.Value of $\leq 0.05$ as Table 4 . Thus statistically the research hypothesis has been proven as follows.

1) The level of disability, family economy, family environment, and school environment has a positive and significant impact on the burden of care for people with disabilities in the Province of Bali. That is, the level of disability, family economy, family environment, and school environment significantly influences the proven and accepted caregiving burden. The results of this study are in line with research by Amin (1995), Zaitun (2017) and Lessenberry \& Rehfeldt (2004) for the level of disability, research Head \& Abbeduto (2007), Joana Briggs Institute (2012), and Triana \& Andriany (2010) for the family economy, research Zaitun (2017), Amaya and Tomasini (2014), and Bogels \& Restifo (2014), for the family environment, and research by Gunadi (2008), Saputra (2016), and Farrel (2008) for the school environment. While the community environment has a positive effect, but not significantly to the burden of care for people with disabilities in the Province of Bali. This means that the community environment has a positive effect on the burden of care for people with disabilities but the effect is not significant. These results indicate that the influence of the community environment on the burden of care is not proven and is not accepted. The results of this study are also in line with research by Ezzat, et al (2017) and Anggraeni and Valentina (2015). 
2) The level of disability, family economy, family environment, school environment, community environment, and parenting cost has a positive and significant impact on the education of children with disabilities in the Province of Bali. This result can be interpreted that the level of disability, family economy, family environment, school environment, community environment, and parenting cost significantly influences the education of children with disabilities proven and accepted. This study is in line with research by Amin (1995), Svetaz et al (2000), and Miftakhuddin (2016) for the level of disability, research by Walker (2013), and Wagner et al. (2005) for the family economy, research by Hurlock (2000), Doren, et al (2014), and Novi, et al (2014) for the family environment, research by Miftakhuddin (2018), Johnsen and Skjorten (2001), and Sutherland \& MacMillan (2001) for the school environment, Miftakhuddin research (2018) for the community environment, and research by Hallahan \& Kauffman (2006), Novi, et al (2014), and Zaitun (2017) for the burden of care.

3) The level of disability, family economy, family environment, school environment, community environment, parenting cost, and education of disabilities children have a positive and significant impact on the independence of persons with disabilities in the Province of Bali. The results of the study can be interpreted that the level of disability, family economy, family environment, school environment, community environment, parenting cost, and education of disabilities children significantly influence the independence of persons with disabilities proven and accepted. This research is in line with Ali and Asronis (2004), and Rizky's (2015) research for the level of disability, Aziz (2019), Wagner, et al (2005), and Walker (2013) for family economics, Hurlock research (2000), Ali and Asroni (2004), and Mazidah (2012) for the family environment, research by Subagya (2011), and Rizky (2015) for the school environment, research by Hamidah, et al (2012), and Effendi and Yunianto (2017) for the community environment, research by Amalia (2014), Dunn, et al (2004) and Alwisol (2004) for the burden of care, and research by Widya (2003), Mirnawati (2018), and Indriana (2004) for the education of children with disabilities.

Analysis of indirect effects, can explain the relationship between research variables (latent variables through the role of intermediate variables. Indirect effects can be seen from the results of the analysis of the total indirect effect values shown in Table 5.

Table 5 - Total Indirect Effects Values (Indirect Effect Variable Research)

\begin{tabular}{|c|c|c|c|c|c|}
\hline Path variable & Coefficient & Standard Deviation & T Statistics & P Values & Information \\
\hline TD $\rightarrow$ PA & 0,080 & 0,043 & 1,860 & 0,063 & Significant \\
\hline $\mathrm{TD} \rightarrow \mathrm{KM}$ & 0,122 & 0,028 & 4,360 & 0,000 & Significant \\
\hline $\mathrm{EK} \rightarrow \mathrm{PA}$ & 0,107 & 0,038 & 2,815 & 0,005 & Significant \\
\hline $\mathrm{EK} \rightarrow \mathrm{KM}$ & 0,124 & 0,037 & 3,327 & 0,001 & Significant \\
\hline $\mathrm{LK} \rightarrow \mathrm{PA}$ & 0,092 & 0,040 & 2,282 & 0,023 & Significant \\
\hline $\mathrm{LK} \rightarrow \mathrm{KM}$ & 0,105 & 0,029 & 3,566 & 0,000 & Significant \\
\hline $\mathrm{LS} \rightarrow \mathrm{PA}$ & 0,231 & 0,061 & 3,811 & 0,000 & Significant \\
\hline $\mathrm{LS} \rightarrow \mathrm{KM}$ & 0,233 & 0,043 & 5,360 & 0,000 & Significant \\
\hline $\mathrm{LM} \rightarrow \mathrm{PA}$ & 0,038 & 0,027 & 1,386 & 0,166 & Not Significant \\
\hline $\mathrm{LM} \rightarrow \mathrm{KM}$ & 0,062 & 0,028 & 2,171 & 0,030 & Significant \\
\hline $\mathrm{BP} \rightarrow \mathrm{KM}$ & 0,181 & 0,064 & 2,831 & 0,005 & Significant \\
\hline
\end{tabular}

Based on Table 5 it is known that the mediation relationship in this test has a significant effect $(P$ values $<0.05$ ) except for the relationship of community environmental variables to the education of children with disabilities through care load that has an insignificant relationship as evidenced by $P$ values $>0.05$. These results indicate that the burden of caregiving does not mediate community environmental variability to the education variable of children with disabilities. This is because the direct influence of the community environment on the burden of care is also not significant.

1) The results of the research analysis found that statistically the level of disability, family economy, family environment, and school environment significantly influences the education of 
children with disabilities through the burden of care in the Province of Bali. This means that the level of disability, family economy, family environment, and school environment significantly influences the burden of child care, furthermore, the burden of child care affects the education of children with disabilities. With the results of statistical testing, this means that the hypothesis is proven to be accepted. These results are in line with Winarsih, et al (2013), Aziz (2019), Wagner, et al (2005), Ainscow, et al (2012), Doll, et al (2013), Mishra and Azeez (2014), Wardhani, et al (2008), Doren, et al (2014), Rizky (2014). Community environmental variables indirectly have an insignificant effect on the Education of Children with Disabilities through the Burden of Care in the Province of Bali. The results of the research analysis showed that the community environment directly had a significant effect on the education of children with disabilities and after mediating the care load variable became insignificant, this showed no mediation (non-mediation) because after mediation it had an insignificant effect. The results of this test state that hypothesis 27 is not proven. These results are in line with Ekadjati (1995), Soetomo (2010), Palijama (2002).

2) Based on the results of data analysis that statistically the relationship between variables of disability level, family economy, family environment, school environment, and community environment indirectly has a significant effect on the independence of persons with disabilities through the education of children with disabilities. The direct effect of the variable level of disability, family economy, family environment, school environment, and the community environment directly has a positive and significant effect on the independence of persons with disabilities, and after going through the education variable of children with disabilities (mediated) also has a significant effect, this shows partial mediation. The results of this test means that the research hypothesis is proven to be accepted. These results are in line with Robinson, et al (1991), Mantey (2014), and Aziz, 2019.

\section{CONCLUSION AND SUGGESTIONS}

The level of disability, family economy, family environment, and school environment directly has a positive and significant effect on the burden of care for people with disabilities in the Province of Bali. The most dominant variable influencing the burden of care for people with disabilities is the school environment, followed by the family economy, family environment, and the level of disability. Whereas the community environment directly has an influence but it is not significant to the burden of care, meaning that the environmental conditions of the community have less effect on the burden of care for people with disabilities in the Province of Bali.

The level of disability, family economy, family environment, school environment, community environment, and the burden of care directly have a positive and significant impact on the education of children with disabilities in the Province of Bali.

The level of disability, family economy, family environment, school environment, community environment, the burden of care and education of children with disabilities directly have a positive and significant impact on the independence of persons with disabilities in Bali Province.

The burden of caregiving as a mediating variable between the level of disability, family economy, family environment, and school environment gives a significant effect on the education of children with disabilities in the Province of Bali. While the influence of the community environment on the education of children with disabilities through the burden of caregiving as a mediating variable has no significant effect.

Education of children with disabilities as mediating variables between the level of disability, family economy, family environment, school environment, community environment, and the burden of care has a significant effect on the independence of persons with disabilities in Bali Province.

Based on the results of this study, the government, NGOs and social organizations to encourage increased access and quality of education for children with disabilities, skills training 
RJOAS, 5(101), May 2020

and empowerment of persons with disabilities to foster independence and fulfill the rights of persons with disabilities.

\section{REFERENCES}

1. Amin, M. 1995. Ortopedagogik Anak Tunagrahita. Jakarta: Direktorat Jendral Pendidikan Tinggi Departemen Pendidikan and Kebudayaan.

2. Ali, M. and Asrori, M. 2008. Psikologi Remaja; Perkembangan Peserta Didik. Jakarta: Bumi Aksara.

3. Alwisol. 2004. Psikologi Kepribadian, Malang: UMM Press.

4. Ainscow, M., Booth, T., Dyson, A., Farrell, P., Frankham, J., Gallannaugh, F., Howes, A., \& Smith, R. 2006. Improving Schools Developing Inclusion. This edition published in the Taylor \& Francis e-Library, New York: Routledge.

5. Amalia, Ayu Diah. 2014. Evaluasi Outcomes bagi Individu Program Rehabilitasi Sosial Disabilitas Netra (Studi Kasus Empat Alumni PSBN Wyata Guna Bandung), Puslitbangkesos, Kementerian Sosial RI.

6. Amaya, ACA and Tomasini. G.A. 2014. Fostering Awareness and Acceptance of Disability in Mexican Mothers of Autistic Children. Journal Psychology, 5, 1355-1365. DOI:10.4236/psych.2014.511146.

7. Anggraeni, N. M. D. A., \& Valentina, T. D. 2015. Penyesuaian psikologis orang tua dengan anak down syndrome. Jurnal Psikologi Udayana, 2(2), 185-197.

8. Astuti, Mulia. 2016. Kemandirian Eks Penerima Manfaat Panti Sosial Bina Daksa, Jakarta: Pusat Penelitian and Pengembangan Kesejahteraan Sosial, Kementerian Sosial RI.

9. Atu Dewi, A. A. Istri Ari,. 2018. Aspek Yuridis Perlindungan Hukum and Pemenuhan Hak Penyandang Disabilitas, Fakultas Hukum Universitas Udayana, Jurnal, http://journal.unnes.ac.id/nju/index.php/pandecta, Volume 13. Number 1. June 2018.

10. Aziz, Mukhamad Abdul. 2019. Motivasi Penyandang Disabilitas Dalam Upaya Meningkatkan Kemandirian Di Perkumpulan Bina Akses Cabang Kabupaten Banyumas, Program Studi Bimbingan and Konseling Islam Fakultas Dakwah Institut Agama Islam Negeri Purwokerto.

11. Beck, A.T. 1985. Causes and Treatment. Philadelphia: University of Pennsylvania Press.

12. Bear, G. G., Kortering, L. J., and Braziel, P., 2006. School Completers and Noncompleters with Learning Disabilities: Similarities in Academic Achievement and Perceptions of Self and Teachers, Remedial and Special Education, 27 (5), 293-300.

13. Braunholtz, T. 2007. Chronic Poverty: An Introduction. https://www.files.ethz.ch/ isn/127205/PB 1.pdf

14. Bogels, S., \& Restifo, K. 2014. Mindful parenting: A guide for mental health practitioners. (N.N. Singh, Ed.). Springer. doi:10.1007/978-1-4614-7406-7

15. Badan Pusat Statistik Provinsi Bali. 2019. Berita Resmi Statistik, https://bali.bps.go.id.

16. Dunn, Caroline; Chambers, Dalee and Rabren, Karen. 2004. 'Variables Affecting Students' Decisions to Drop Out of School." Remedial and Special Education, 25.5 (2004): 314-23

17. Direktorat Pembinaan Sekolah Luar Biasa. 2005. Identifikasi Anak Berkebutuhan Khusus Dalam Pendidikan Inklusif, Jakartsa: Direktorat Pembinaan Sekolah Luar Biasa.

18. Doll, J. J., Eslami, Z \& Walters, L. 2013. Understanding Why Students Drop Out of High School, According to Their Own Reports: Are They Pushed or Pulled, or Do They Fall Out? A Comparative Analysis of Seven Nationally Representative Studies. Retrieved on $10^{\text {th }}$ November $2017 \quad$ from http://www.journals .com/doi/full/10.1177/2158244013503834.

19. Doren, B., Murray C., and Gau, J. M. 2014. Salient Predictors of School Dropout among Secondary Students with Learning Disabilities, Article in Learning Disabilities Research and Practice, November 2014. 
20. Direktorat PLB. 2014. Mengenal Pendidikan Terpadu Jakarta: Dirjen Dikdasmen, Depdiknas, 2004).

21. Dinas Pendidikan Provinsi Bali. 2019. Profil and Informasi Pendidikan 2019, Denpasar.

22. Ekadjati, E. 1995. Kebudayaan Sunda (Suatu Pendekatan Sejarah). Jakarta: Dunia PustakaJaya.

23. Effendi, Arief Burhan,dan Rahaditya Yunianto. 2017. Implementasi Diversity Program Bagi Tenaga Kerja Penyandang Disabilitas Pada PT. Wangta Agung Kota Surabaya. Indonesian Journal of Disability Studies (IJDS). 2017: Vol. 04(02): pp. 96-103.

24. Ezzat, O., Bayoumi, M., \& Samarkandi, O. A. 2017. Quality of Life and Subjective Burden on Family Caregiver of Children with Autism, 6(1), 33-39.

25. Farrel, Michael, 2008. Inclusion at the Crossroads, Special Education-Concept and Values. USA: David Fulton Publisher.

26. Gilley, J.W. and S.A.Eggland. 1996. Principle of Human Resources Development, Addison Wesley, New York.

27. Gunadi, Tri. 2008. Terapi Sensori Integrasi up Date Untuk Anak Autism. Autism Awareness Festival, Jakarta.

28. Hurlock, E.B. 2000. Psikologi Perkembangan: Suatu Pendekatan sepanjang Rentang Kehidupan. Alih Bahasa: Wasana, Erlangga, Jakarta.

29. Head \& Abbeduto. 2007. Recognizing The Role of Parents in Developmental Outcomes: A Systems Approach to Evaluating The Child With Developmental Disabilities, Mental Retardation and Developmental Disabilities, Research Reviews, 13: 239-301

30. Hamidah, S. A. Kartini, S. M. \& Karyanta, N. A. 2012. Hubungan Antara Penerimaan Diri and Dukungan Sosial dengan Kemandirian pada Penyandang Cacat Tubuh di Balai Besar Rehabilitasi Sosial Bina Daksa (BBRSD) Prof. Dr. Soeharso Surakarta. Jurnal Vol 1 No 2.Surakarta: Universitas Sebelas Maret.

31. Hallahan, D.P. \& Kauffman, J.M. (2006). Exceptional Learners: Introduction to Special Education 10th ed. United States of America: Pearson.

32. Indriana, Y. 2004. Kepuasan Hidup Orang Lanjut Usia Dalam Hubungannya dengan Jenis Aktivitas, Jenis Kelamin, Religiusitas, Status Perkawinan, Tingkat Kemandirian, Tingkat Pendidikan and Daerah Tempat Tinggal. Jurnal Psikologi. Semarang: Fakultas Psikologi Universitas Diponegoro. Vol. 1. No. 1 (1-13)

33. Jones, Steve. 1997. Virtual Culture: Introduction, Sage Publication, London.

34. Johnsen, Berit H. and Skjorten, Miriam D. 2001. Education - Special Needs Education, Unifub Forlag, University of Oslo, http://www.idpeurope.org/docs/uio_upi_inclusion_book/6 menuju_inklusi_dan_pengayaan.php,

35. Jemta, Fugl-Meyer, Oberg, \& Dahl. 2008. Self-esteem in children and adolescents with mobility impairment: Impact on well-being and coping strategies, https://www.researchgate.net/publication/23443910.

36. Johnson, Eileen S. 2008. Ecological Systems and Complexity Theory: Toward an Alternative Model of Accountability in Education, Complicity: An International Journal of Complexity and

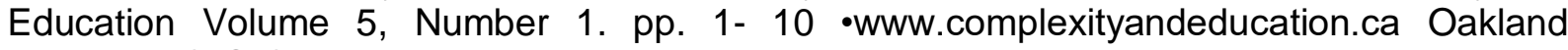
University (USA).

37. Joana Briggs Institute. 2012. Caregiver burden of terminally-ill adults in the home setting. Nursing \& Health Sciences, (June), 435-437.

38. Kadji, Yulianto. 2013. Kemiskinan and Konsep Teoritisnya, Fakultas Ekonomi and Bisnis Universitas Negeri Gorontalo.

39. Lessenberry, B. M., \& Rehfeldt, R. A. 2004. Evaluating stress levels of parents of children with disabilities. Journal of exceptioanl children. (70). 231-244.

40. Novi Lindaswari, I Gusti Agung., Ni Luh Putu Yunianti Sutari C., Dian Adriana. 2015. Hubungan Mekanisme Koping dengan Pola Asuh Orang Tua Anak Retardasi Mental Ringan 
di Sekolah Luarbiasa C Negeri Denpasar. https://ojs.unud.ac.id/index.php/coping/ article/view/10778

41. Midgley, J. 2000. Globalization, Capitalism and Sosial Welfare: A Sosial Development Perspective. Canadian Sosial Work, Special Issue: Sosial Work and Globalization, 2(1):13-28

42. Monks, F.J., Knoers, A.M. P.\& Haditono, S.R. 2006. Psikologi Perkembangan Pengantar dalam berbagai bagiannya. Yogyakarta: Gadjah Mada University Press.

43. Mazidah, L. 2012. Kesejahteraan Psikologis Tuna Netra Dewasa Dini. Universitas Islam Negeri Sunan Kalijaga, Fakultas IImu Sosial and Humaniora. Yogyakarta

44. Mantey, Efua Esaaba. 2014. Accessibility to inclusive education for children with disabilities: a case of two selected areas in Ghana, Dissertation for the award of philosophy of Doctorate Degree, Department of Educational Science/Psychology, Siegen, Germany, https://dnb.info/1068362936/34.

45. Mishra, Pratibha J. and Abdul Azeez E.P. 2014. Family Etiology of School Dropouts: A Psychosocial Study. International Journal of Multidisciplinary Approach and Studies. Volume 01, No.1, Jun2 2014.

46. Miftakhuddin. 2018. Kecenderungan Putus Sekolah Difabel Usia Pendidikan Dasar di Jember, Journal of Disability Studies Vol. V, No. 1, Januari-Juni 2018, h. 95-114 DOI: 10.14421/ijds.050105

47. Mirnawati. 2018. Pembelajaran Bina Diri Bagi Anak Tunagrahita di Sekolah, http://eprints.ulm.ac.id/id/eprint/4130, Universitas Lambung Mangkurat, Banjarmasin.

48. Palijama, Fientje. 2002. Rehabilitasi Sosial Anak Cacat (Penerapan Prinsip Pengasuhan Anak Cacat Oleh Panti Sosial Bina Asih Leleani di Kota Ambon). Thesis Program Pascasarjana, IImu Kesejahteraan Sosial, Bidang IImu Sosial Universitas Indonesia. http://lib.ui.ac.id/detail?id=71720

49. Robinson, P.B., Stimpson, D.V., Huefner, J.C., \& Hunt, H.K. 1991. An attitude approach to the prediction of entrepreneurship. Entrepreneurship Theory \& Practice, Summer, 15(4), 13 30. Baylor University.

50. Rumberger, R.W. and Larson, K.A. 1998. Student mobility and the increased risk of high school drop out. American Journal of Education, 107, 1-35.

51. Rizky, Ulfah Fatmala. 2014. Identifikasi Kebutuhan Siswa Penyandang Disabilitas Pasca Sekolah Menengah Atas, Indonesian Journal of Disability Studies, Vol. 1 Issue 1 pp. 52-59, June 2014.

52. Rizky N.A, Ravika. 2015. Kemandirian Pada Dewasa Difabel, Naskah Publikasi, Fakultas Psikologi, Universitas Muhammadiyah Surakarta.

53. Salim, E. 1980. Pembangunan Ekonomi and Pemerataan, Idayu, Jakarta.

54. Sakamota, A. and Powers, P.A. 1995. Education and the dual labour market for Japanaese, American Sociological Review. 60 (2) P. 222-246.

55. Steinberg, Laurence. 1995. Adolescene, Sanfrancisco: McGraw-Hill Inc.

56. Svetaz, M. V., Ireland, M., \& Blum, R. 2000. Adolescents with learning disabilities: Risk and factors associated with emotional well-being: findings from the national longitudinal study of adolescent health. Journal of Adolescent Health, 27, 340-348. doi: http://dx.doi.org/10.1016/S1054-139X(00)00170-1

57. Sutherland, Maura B. and MacMillan, Robert C. 2001. Preventing high school dropout among students with mild disabilities: A literature review. InSpecial Education and Communication Disorders Faculty Publications.Paper4.Availableat:http://vc.bridgew.edu/spec_commdis_fac/4

58. Santrock, John W. 2003. Adolesence Perkembangan Remaja, Jakarta: Erlanḡga.

59. Soetomo. 2010. Masalah Sosial and Upaya Pemecahannya, Yogyakarta: Pustaka Pelajar.

60. Santrock, J. W. 2010. Psikologi Pendidikan, Jakarta: Kencana.

61. Subagya. 2011. Pusat Sumber, Pendidikan Khusus and Peran and Tugas Guru Pembimbing Khusus (GPK). Makalah pada Workshop Pendidikan Inklusi tanggal 18 Januari 2011 di FKIP UNS Surakarta 
62. Saputra, Angga. 2016. Kebijakan Pemerintah Terhadap Pendidikan Inklusif, Jurnal IImiah Tumbuh Kembang Anak Usia Dini, Volume. 1 No. 3. September 2016 e-ISSN: 2502-3519.

63. Singal, N., Ware. H.,\& Bhutani. S. K. 2017. Inclusive Quality Education for Children with Disabilities, Technical Report, November 2017, See discussions, stats, and author profiles for this publication at: ttps://www.researchgate.net/ publication/321213728

64. Todaro. 2004. Ekonomi Pembangunan. Yogyakarta: BPFE Universitas Gadjah Mada Yogyakarta.

65. Triana, NY. Andriany, M. 2010. Stres and Koping Keluarga Dengan Anak Tunagrahita di SLB C and SLB C1 Widya Bhakti Semarang. http://eprints.undip.ac.id/16469/3/Jurnal.pdf. Diakses tanggal 16 Januari 2020.

66. UNESCO (2009). Inclusion of children and disabilities: the early childhood imperative. UNESCO Policy Brief on Childhood. http://unesdoc.unesco.org/images/0018/001831/183156e.pdf.

67. Widya, Mamad. 2003. Bina Diri Bagi Anak Berkebutuhan Khusus (ABK). Jakarta: Universitas Terbuka.

68. Wagner, M., Newman, L., Cameto, R., Garza, N., \& Levine, P. 2005. After high school: A first look at the postschool experiences of youth with disabilities. A report from the National Longitudinal Transition Study 2 (NLTS2). Menlo Park, CA: SRI International.

69. Wardhani, M. K., Rahayu, M. S., \& Rosiana, D. 2008. Hubungan antara Personal Adjustment dengan Penerimaan terhadap Anak Berkebutuhan Khusus pada Ibu yang Memiliki Anak Berkebutuhan Khusus di RSUD X. In Seminar Nasional Penelitian and Pengabdian Kepada Masyarakat (pp. 49-54). Bandung: UNISBA. [online]. http:// proceeding.unisba.ac.id/index.php/sosial/article/view/204.

70. Winarsih, Sri (Tim Penyusun), 2013. Buku Panduan Penanganan Anak Berkebutuhan Khusus (ABK), Kementrian Pemberdayaan Perempuan and Perlindungan Anak, Jakarta.

71. Walker, Jo. 2013. Equal Right, Equal Opprtunity. Inclusive Education For Children With Disabilities. Global Campaign for Education, Handicap International.

72. Zaitun. 2017. Pendidikan Anak Berkebutuhan Khusus, Pekanbaru: Kreasi Edukasi, Publishing and Consulting Company Pekanbaru. 